\title{
The effect of telomerase expression on the escape from M2 crisis in virus-transformed human retinal pigment epithelial cells
}

\author{
Jae-Kyung Park', Byung-Ho Kim²,4, \\ Yo Seb Han' and In Kook Park \\ ${ }^{1}$ East-West Medical Research Institute, Kyung Hee Medical Center, \\ Seoul 130-702, Korea \\ ${ }^{2}$ Department of Internal Medicine, Kyung Hee University College of \\ Medicine, Seoul 130-702, Korea \\ ${ }^{3}$ Department of Biology, Dongguk University, Seoul 100-715, Korea \\ ${ }^{4}$ Corresponding author: Tel, +82-2-958-8145; \\ Fax, +822-968-1848; E-mail, kimbh@ khmc.or.kr
}

Accepted 3 April 2002

Abbreviations: FBS, fetal bovine serum; $h T E R T$, human telomerase reverse transcriptase; $M 1$, mortality stage $1 ; \mathrm{M} 2$, mortality stage 2; RPE, retinal pigment epithelium; SV40, simian virus 40; TRAP, telomerase repeat amplification protocol; tsT, temperature-sensitive (mutant of) SV40 large T antigen.

\begin{abstract}
Transformation with viral oncogene extends the lifespan of normal cells beyond replicative senescence called M1, but most of them eventually succumb to second crisis called M2 when telomeres become critically short. To acquire an infinite growth capacity, these cells have to overcome M2 crisis, which is known to follow telomerase activation. We have investigated if telomerase expression is required for virus-transformed pre-M2 cells to avert M2 crisis. Human retinal pigment epithelial (RPE) cells were transformed with simian virus 40 large $T$ antigen and a VR3 clone in pre-M2 stage was obtained. Then, VR3 cells were transfected with a telomerase-containing vector and two cell lines that expressed telomerase temporarily or continuously were cloned and designated as ST1 and ST2, respectively. Normal RPE cells went into senescence after 36 population doublings. Although the lifespan was extended in the VR3 clone about 20 times more, it eventually underwent second crisis. The telomere length of VR3 decreased compared to that of normal RPE cells and the decrease continued during subculture. However, the ST1 and ST2 clones that expressed both $\mathrm{T}$ antigen and telomerase could avert this crisis. The initial telomere length of ST1 and ST2 was longer than that of normal cells. The
\end{abstract}

ST1 underwent growth arrest again as telomerase expression faded out and elongated telomere was shortened, but the ST2 that maintained telomerase activity and telomere length proliferated continuously. In conclusion, telomerase activation is definitely required to overcome M2 crisis and acquire an infinite lifespan in human somatic epithelial cells and this mechanism is independent from M1 crisis escape in cell immortalization.

Key Words: Cell crisis, Human retinal pigment epithelial cells, Immortalization, Telomerase, Telomere, Temperature-sensitive SV40 large T antigen

\section{Introduction}

Normal human somatic cells in culture have a finite lifespan and enter a non-dividing state termed replicative senescence (Hayflick et al., 1961; Goldstein 1990). It is dependent upon cumulative cell divisions and not chronologic or metabolic time, indicating that proliferation is limited by a mitotic clock (Dell'Orco et al., 1973; Harley, 1991). In primary human somatic cells, the telomere was shortened with replicative age because telomerase is not expressed unlike germline cells. Thus, this telomere loss is thought to control entry into senescence (Harley et al., 1990; Hastie et al., 1990).

Simian virus 40 (SV40) large T antigen binds to p53 and pRB, which inhibit normal cellular senescence (Levine, 1990 ) and can lead to cell immortalization in a rare event (Wright, et al., 1989). Wright et al. have proposed a twostage model for human cell immortalization. They described normal senescence as mortality stage 1 (M1, Hayflick limit) and T antigen induced crisis as mortality stage 2 (M2). There are two main assumptions in this model. One is that $\mathrm{M} 1$ and $\mathrm{M} 2$ are caused by independent mechanisms. The other is that the M1 mechanism is retained but suppressed by $T$ antigen in both extended growth phase and immortal cells.

At M1 stage, there is presumed critical telomere loss on a few chromosomes signaling irreversible cell cycle arrest, replicative senescence. The T antigen leads cells to avert normal senescence and extend their lifespan. However, most of these pre-M2 cells enter M2 crisis when telomeres are critically shortened on a large number of chromosomes. Rare clones that activate telomerase are known to escape M2, stabilize chromosomes, and 
acquire an infinite growth capacity (Harley et al., 1994).

Previous studies have indicated that ectopic expression of human telomerase reverse transcriptase (hTERT) enables fibroblasts to circumvent senescence (Bodnar et al., 1998; Vaziri et al., 1998). However, it is not clear that these cells can also surmount M2 crisis, and the result can be generally applied to various cell types. In this study, we tried to reveal if telomerase expression is required for virally transformed pre-M2 human epithelial cells to overcome M2 crisis which leads to immortalization and this mechanism is independent from M1 crisis as far as cellular senescence is concerned.

\section{Materials and Methods}

\section{Recombinant retrovirus expressing temperature- sensitive SV40 large T antigen (tsT)}

A $\varphi-2$ derived producer cell line for an amphotropic recombinant retrovirus containing the genes encoding tsT (early region mutant tsA58) and neomycin phosphotransferase was kindly provided by Dr. J. RoyChowdhury of the Liver Research Center, Albert Einstein College of Medicine, NY, USA. The tsT is active at a permissive temperature of $33^{\circ} \mathrm{C}$, but inactivated at a non-permissive temperature of $39^{\circ} \mathrm{C}$.

At $18 \mathrm{~h}$ after the addition of fresh medium, supernatant containing the recombinant retrovirus, was harvested from subconfluent culture plates of the producer cells. Then, it was filtered through $0.45 \mu \mathrm{m}$ filters and frozen at $-70^{\circ} \mathrm{C}$ until its use as the source of infection for human RPE cells.

\section{Preparation of human RPE cells and retroviral infection}

RPE cells were isolated from the uvea of freshly dissected eye with a mixture of $0.05 \%$ trypsin-EDTA solution and cultivated using DMEM (Gibco BRL, Grand Island, NY, USA) containing $10 \%$ fetal bovine serum (FBS), $10 \mathrm{ng} / \mathrm{ml}$ of epidermal growth factor, $10 \mu \mathrm{g} / \mathrm{ml}$ of insulin, $5 \times 10^{-7} \mathrm{M}$ of hydrocortisone, $10^{-4} \mathrm{M}$ of ethanolamine, $10^{-4} \mathrm{M}$ of phsphoethanolamine, $0.1 \mu \mathrm{g} / \mathrm{ml}$ of cholera toxin, $20 \mathrm{pM}$ of triiodothyronine, $0.18 \mathrm{mM}$ of adenine, $5 \mu \mathrm{g} / \mathrm{ml}$ of transferrin, and $100 \mu \mathrm{g} / \mathrm{ml}$ of bovine pituitary extract on $10 \mathrm{~cm}$ culture dishes in $95 \%$ air, $5 \% \mathrm{CO}_{2}$ atmosphere at $37^{\circ} \mathrm{C}$. When RPE cells grew to form monolayer, they were splitted into the ratio of 1:4 for serial subculture.

RPE cells were infected at $60-70 \%$ confluent state with a $5 \mathrm{ml}$ viral stock per plate in the presence of $8 \mu \mathrm{g} /$ $\mathrm{ml}$ polybrene (Aldrich chemical Co., Milwaukee, WI, USA) at $37^{\circ} \mathrm{C}$ for $4 \mathrm{~h}$. The virus-containing medium was then aspirated and the culture was maintained in the above hormonally defined DMEM at $33^{\circ} \mathrm{C}$. Mockinfected cell culture was also performed with the same method but the supernatant did not contain the retrovirus. Four days later, neomycin-resistant clones were selected by adding the neomycin analogue G418 $(400 \mu \mathrm{g} / \mathrm{ml}$, Sigma Chemical Co., St. Louis, MO, USA). The G418-resistant colonies were isolated using the cloning cylinder, trypsinized, and expanded by culturing at $33^{\circ} \mathrm{C}$ with $1: 4$ split.

\section{Transfection of human telomerase expressing vector}

The pGRN145 vector (Weinrich et al., 1997) was kindly provided by Geron Corporation, Menlo Park, CA, USA. This vector encodes hTERT with a consensus Kozak sequence downstream of the myeloproliferative sarcoma virus promotor and hygromycin-B for selection. T antigenexpressing RPE cells were subjected to electroporation to transfect pGRN145.

Cells in suspension $\left(500 \mu \mathrm{l}, 10^{6} \mathrm{cells} / \mathrm{ml}\right)$ were mixed with $10 \mu \mathrm{g}$ of plasmid in HEPES-buffered saline $(21 \mathrm{mM}$ HEPES pH 7.05, $137 \mathrm{mM} \mathrm{NaCl}, 5 \mathrm{mM} \mathrm{KCl}, 0.7 \mathrm{mM}$ $\mathrm{Na}_{2} \mathrm{HPO}_{4}, 6 \mathrm{mM}$ glucose) in $0.4 \mathrm{~cm}$ cuvettes, and electroporated at $200 \mathrm{~V}, 800 \mu$ Farad capacitance and low $\Omega$ position using the Cell-Porator (Gibco BRL). After the electroporation, the cells were plated in fresh DMEM containing $10 \%$ FBS and cultured at $33^{\circ} \mathrm{C}$ for $48 \mathrm{~h}$. Then, they were placed into medium containing hygromycin-B $(50 \mu \mathrm{g} / \mathrm{ml})$ for 2 to 3 weeks. The concentration of hygromycin-B was reduced to $10 \mu \mathrm{g} / \mathrm{ml}$ and maintained during the selection of transfected cells. Individual stable clones were selected using the cloning cylinder and used to analyze various characteristics.

\section{The proliferation limit and growth pattern of the cells}

The cells were maintained in $10 \mathrm{~cm}$ culture dishes at $33^{\circ} \mathrm{C}$ and fed with fresh DMEM containing $10 \%$ FBS twice a week. When cultures became confluent, the cells were trypsinized and subcultured at a dilution of $1: 4$ until the cells underwent replicative senescence. In order to measure the growth rate, the cells were plated at a density of $1 \times 10^{5}$ cells per $3.5 \mathrm{~cm}$ plate and incubated at $33^{\circ} \mathrm{C}$ for up to 5 days. Then, the cells were released with the trypsin and counted.

\section{Expression of SV40 large T antigen}

To determine the $T$ antigen content, the cells were cultured at a permissive $\left(33^{\circ} \mathrm{C}\right)$ and a non-permissive temperature $\left(39^{\circ} \mathrm{C}\right)$ for 2 days and Western blot analysis was performed (Kim et al., 2000). COS-7 cells and normal RPE cells were used as positive and negative controls, respectively.

Twenty microgram of cell homogenates were subjected to $7.5 \%$ SDS-polyacrylamide gel electrophoresis and electroblotted to polyvinylidene difluoride membrane (Millipore Corp., Bedford, MA, USA). Immunotransblot was performed using mouse monoclonal antibodies against $T$ antigen (500 times dilution, Oncogene Science, Cambridge, MA, USA) and peroxidase-conjugated 
sheep anti-mouse IgG antibody (1:3,000, Amersham, Buckinghamshire, England). The proper bands were detected with chemoluminescent substrates $\left(\mathrm{ECL}^{\mathrm{TM}} \mathrm{Kit}\right.$, Amersham).

\section{Telomerase activity}

Telomerase activity was measured by telomerase repeat amplification protocol (TRAP) assay (Kim et al., 1994) using a commercial kit (TRAPeze, Phamingen, San Diego, CA, USA). After cell harvest, the cells were lysed by being mixed with cold CHAPS extraction buffer $\left(5 \times 10^{4}\right.$ cells $\left./ 100 \mu \mathrm{l}\right)$ and placed in ice for $30 \mathrm{~min}$. The mixture was centrifuged at $16,000 \mathrm{~g}$ for $20 \mathrm{~min}$ and the supernatant was stored at $-80^{\circ} \mathrm{C}$ in aliquots until assay.

The TRAP reaction was performed in $50 \mu$ l of TRAP buffer containing $1 \mu \mathrm{g}$ of cell homogenate in $2 \mu \mathrm{l}, 5 \mu \mathrm{l}$ of 10x TRAP buffer, $1.5 \mu$ l of $\gamma-{ }^{32} \mathrm{P}$ labeled TS primer (5'AATCCGTCGAGCAGAGTT-3', $0.1 \mu \mathrm{g} / \mathrm{l}), 1 \mu \mathrm{l}$ of dNTPs $(50 \mu \mathrm{mol} / \mathrm{l}), 1 \mu \mathrm{l}$ of internal control primers (RP and K1 primers, TSK1 template), $0.5 \mu$ l of Taq polymerase (10 unit/ $\mu \mathrm{l})$, and $39 \mu \mathrm{l}$ of DEPC treated water. Reaction tubes were placed in a thermocycler (Perkin-Elmer 9600 , USA) for $30 \mathrm{~min}$ at $30^{\circ} \mathrm{C}$, followed by 30 cycles of polymerase chain reaction at $94^{\circ} \mathrm{C}$ for $30 \mathrm{~s}$ and $59^{\circ} \mathrm{C}$ for $30 \mathrm{~s}$. A half of the amplified products were resolved on a $12.5 \%$ non-denaturing polyacrylamide gel in $0.5 x$ TBE buffer. Then, the gel was dried and visualized by autoradiography after 2 to $4 \mathrm{~h}$ exposure at $-70^{\circ} \mathrm{C}$. To validate the TRAP assay data, we used internal PCR amplification control, heat-inactivated control, biologic telomerase positive control (293 cells) and primer-dimer/ PCR contamination control.

\section{Telomere length}

The length of telomere was measured following the direction of a commercial kit (The Telomere Legnth Assay Kit, Pharmingen). Cellular genomic DNA was digested to the completion with Rsal and Hinf to produce terminal restriction fragment (TRF). TRF was resolved on $0.6 \%$ agarose gel using $1 \times$ TAE buffer and electroblotted to nylon membranes. Then, Southern hybridization was performed using biotinylated telomere probe at the concentration of $10 \mathrm{ng} / \mathrm{ml}$. After washing the membrane with $2 x \mathrm{SSC} / 0.1 \%$ SDS, TRF was detected by autoradiography after reacting with a working solution of Streptavidin-HPR. To compare the length of TRF, we used biotinylated $\lambda$ DNA/BstEII marker, biotinylated $\lambda$ DNA/HindIII marker, HL60 cells (3.3 kb), and 293 cells (11.3 kb).

An estimate of the TRF length was obtained by comparing the size of the signal smear measured on a densitometric scan of the autoradiogram to the molecular weight markers as indicated in the manual of the kit.

\section{Origin of expressed telomerase}

Reverse transcriptase-polymerase chain reaction (RTPCR) was performed to confirm the origin of expressed hTERT mRNA in cells transfected with pGRN145. Endogenous hTERT mRNA was detected with the primer set RA58 (sense, 5'-GGCTGAAGTGTCACAG-3', 2991-2976) and hTERT 3'UTR (anti-sense, 5'GGCTGC TGGTGTCTGCTCTCGGCC-3', 3475-3498). Exogenous hTERT mRNA was detected with the primer set RA58 (sense, 7160-7175 in pGRN145 sequence) and RA55 (anti-sense, 5'TCCGCACGTGAGAAT-3', 7670-7685 in pGRN145 sequence) (Bodnar et al., 1998).

RT-PCR was performed with cDNA synthesis reaction kit (Boehringer Mannheim, Roche Diagnostic $\mathrm{GmbH}$, Sandhofer Strasse, Germany). One microgram of RNA from the cells was mixed with $4 \mu$ of $5 x$ RT reaction buffer $\left(250 \mathrm{mM}\right.$ Tris- $\mathrm{HCl}, 150 \mathrm{mM} \mathrm{KCl}, 30 \mathrm{mM} \mathrm{MgCl}_{2}$, $50 \mathrm{mM}$ DTT, pH 8.3), 20 units of RNase inhibitor, 20 units of AMV reverse transcriptase. For CDNA synthesis, the mixture was incubated at $42^{\circ} \mathrm{C}$ for $60 \mathrm{~min}$. Then, $5 \mu \mathrm{l}$ of the cDNA were mixed with $5 \mu \mathrm{l}$ of $10 \mathrm{x}$ PCR buffer $(500 \mathrm{mM}$ Tris, $100 \mathrm{mM} \mathrm{KCl}, 15 \mathrm{mM} \mathrm{MgCl}$ ), 0.5 $\mu \mathrm{l}$ of $10 \mathrm{mM}$ dNTP, 20 pmol of each primer, and 2 units of Taq polymerase. The final volume was adjusted to 50 $\mu \mathrm{l}$ with distilled water and followed by 35 cycles of PCR $\left(95^{\circ} \mathrm{C}\right.$ for $40 \mathrm{~s}, 56^{\circ} \mathrm{C}$ for $60 \mathrm{~S}$, and $72^{\circ} \mathrm{C}$ for $\left.60 \mathrm{~s}\right)$.

\section{Results}

\section{The morphology of various cell lines}

During the transformation of normal RPE cells with tsT, a $\mathrm{T}$ antigen-expressing cell line was cloned and designated as VR3. The VR3 cells were used for the transfection of hTERT. Two telomerase-expressing cell lines were cloned. One expressed human telomerase temporarily and the other expressed it continuously. We designated them as ST1 and ST2, respectively. The normal RPE, VR3, ST1, and ST2 cells were used for analysis (Figure 1).

Normal RPE cells at the second subculture show polygonal shape and melanin granules in their cytoplasm. Various transformed cells showed different morphology from normal RPE cells, but there is no significant difference in their epithelial morphology.

\section{The proliferation limit of the cells}

Normal RPE cells entered replicative senescence after 36 population doublings (PD) and almost stopped dividing when their population doubling time (PDT) was about $247 \mathrm{~h}$ (Figure 2). The $\mathrm{T}$ antigen transformation extended their lifespan about 20 PD more, that is, the VR3 clone underwent crisis after PD 60 when its PDT was about $222 \mathrm{~h}$. These results indicate that the point of M1 and M2 in human RPE cells is PD 36 and PD 60, respectively. 

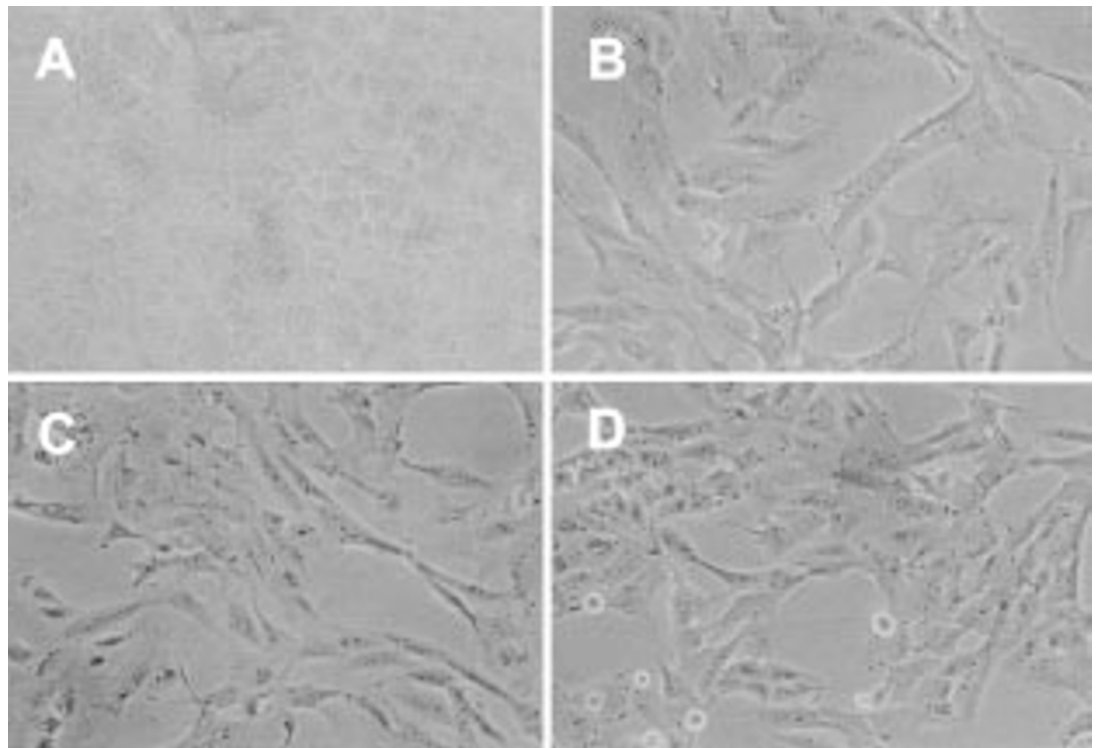

Figure 1. Morphology of normal and various transformed RPE cells. (A) Normal RPE cells at the second subculture show melanin granules in their cytoplasm and polygonal shape. (B) The morphology of VR3 cell line cloned from normal RPE cells after transforming with the temperature-sensitive mutant of SV40 T antigen is shown. (C, D) The morphology of ST1 and ST2 cell lines cloned from VR3 cells after transfecting hTERT is shown. The ST1 clone expressed T antigen continuously but telomerase temporarily. In contrast, the ST2 clone expressed both T antigen and telomerase continuously. There is no significant difference in their morphology. Phase contrast microscopy x 100.

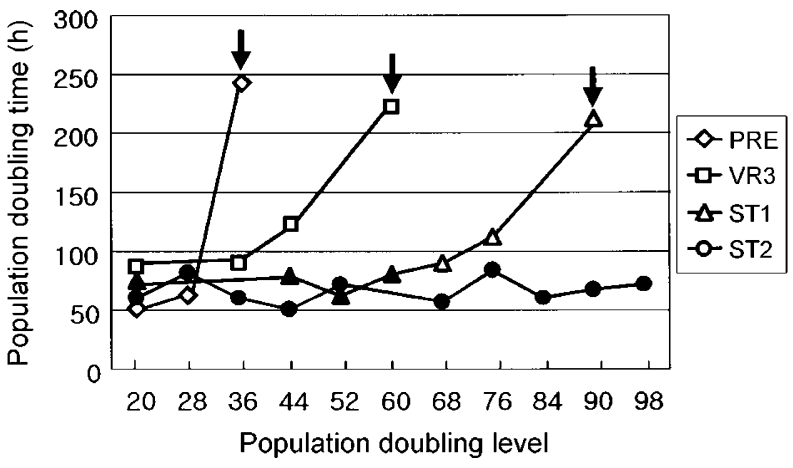

Figure 2. Proliferation limit of various cell lines. Normal RPE cells entered replicative senescence at population doubling (PD) 36 when their population doubling time (PDT) was about $247 \mathrm{~h}$. The lifespan of T antigenexpressing VR3 clone was extended up to PD 60 when its PDT was about $222 \mathrm{~h}$. The ST1 and ST2 clones that expressed both T antigen and telomerase could proliferate more than 90 times of PD. The ST1 clone went into almost growth arrest at PD 90 when its PDT was about $212 \mathrm{~h}$ as telomerase expression faded out after PD 62. In contrast, the continuously telomerase-expressing ST2 clone maintained the similar growth rate. Open diagrams mean that telomerase is not expressed in those cells and vice versa in closed diagrams. Arrows indicate that the cells entered replicative senescence. Note that telomerase expression extinguished after PD 60 in the ST1 clone that expressed it initially.

To test the effect of ectopic expression of hTERT on M2 crisis in pre-M2 RPE cells, hTERT was transfected into VR3 cells at PD 20, then hTERT expressing clones were selected. As mentioned above, those cell lines were designated as ST1 and ST2. The ST1 expressed telomerase temporarily and the ST2 expressed it continuously. These clones proliferated beyond $\mathrm{M} 2$ crisis and divided more than 90 times of PD. The growth rate of the ST1 was decreasing after PD 76 and went into crisis again at PD 90 when its PDT was about 212 h. However, the ST2 maintained the similar growth rate with no sign of crisis and proliferated continuously for more than 120 times of PD.

\section{Expression of $\mathrm{T}$ antigen}

$T$ antigen was expressed at a permissive temperature in all transformed cell lines (VR3, ST1 and ST2), but not in normal RPE cells. At a non-permissive temperature, the expression was decreased or not appeared (Figure 3). These results suggested that VR3, ST1 and ST2 clones were transformed with the temperature-sensitive mutant of SV40 large T antigen.

\section{Telomerase activity}

There was no telomerase activity in normal RPE cells and the VR3 clone up to PD 57 (Figure 4A). The ST1 clone showed strong telomerase activity at earlier passage (PD22), but the activity decreased along with the increment of $\mathrm{PD}$ and completely disappeared at PD 72 (Figure 4A). Unlike the ST1, the ST2 clone showed strong and continuous expression of telomerase up to PD 98 (Figure 4B).

\section{The change of telomere length}

The telomere length of normal RPE cells was initially similar with that of 293 control cells. However, it gradually reduced from $8.4 \mathrm{~kb}$ to $7.2 \mathrm{~kb}$ about $80 \mathrm{bp}$ loss 


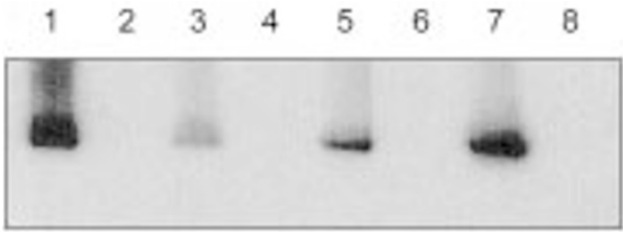

Figure 3. Expression of $T$ antigen in various cell lines. $T$ antigen is expressed at a permissive temperature $\left(33^{\circ} \mathrm{C}\right)$, but disappeared at a nonpermissive temperature $\left(39^{\circ} \mathrm{C}\right)$ in all three transformed cell lines (VR3, ST1, and ST2). Normal RPE cells do not show any T antigen expression. Lane 1, COS-7 cells as a positive control; lane 2, normal RPE cells; lane 3, VR3 at $33^{\circ} \mathrm{C}$; lane 4, VR3 at $39^{\circ} \mathrm{C}$; lane $5, \mathrm{ST} 1$ at $33^{\circ} \mathrm{C}$; lane $6, \mathrm{ST} 1$ at $39^{\circ} \mathrm{C}$; lane 7 , ST2 at $33^{\circ} \mathrm{C}$; lane $8, \mathrm{ST} 2$ at $39^{\circ} \mathrm{C}$.

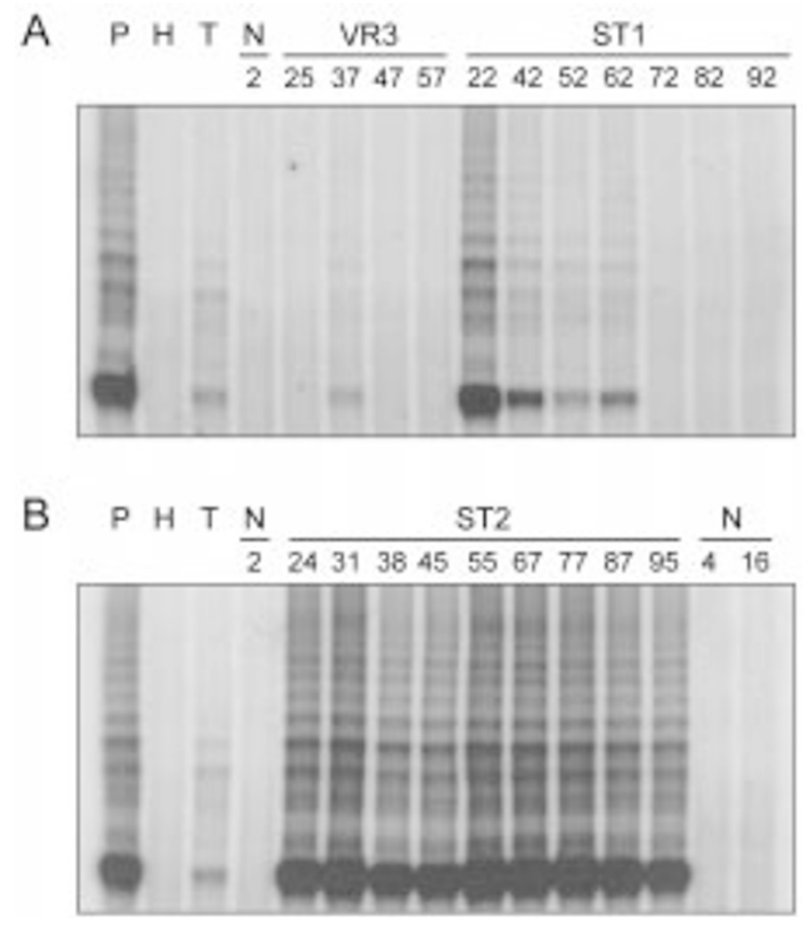

Figure 4. Telomerase expression and its change in various cell lines with serial subculture. (A) There was no telomerase activity in the VR3 clone up to PD 57. The ST1 clone showed strong telomerase activity at earlier passage, but the activity decreased with serial subculture and was not shown at PD 72. (B) Telomerase was expressed continuously in the ST2 clone. The numbers below N, ST1, VR3, and ST2 indicate population doublings. P, postive control (KATO III); $\mathrm{H}$, heated control; T, TSR8 control (for the measurement of activity); N, negative control (normal RPE cells, for the detection of primer-dimer/ PCR contamination).

per doubling as cells divided (Figure $5 \mathrm{~A}$ ). The telomere length of VR3 clone was shortened progressively from $7.8 \mathrm{~kb}$ to $5.8 \mathrm{~kb}$, which is shorter than that of normal RPE cells (Figure 5B). The initial telomere length of the ST1 and ST2 clones (14 kb) was longer than that of normal cells, but two cell lines showed different patterns of its change as they proliferated. The length was shortened progressively in the ST1 clone, but not in the ST2 clone, it was extended gradually up to $23 \mathrm{~kb}$ at PD
A
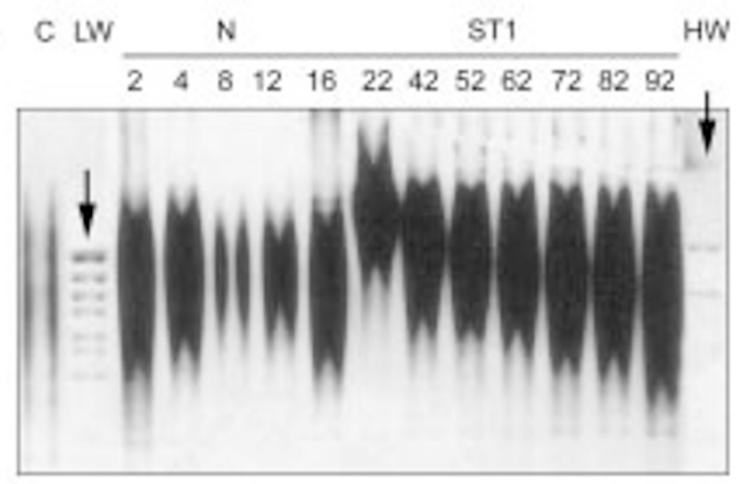

B

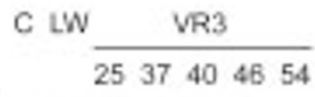

$\mathrm{ST2}$

$H W$

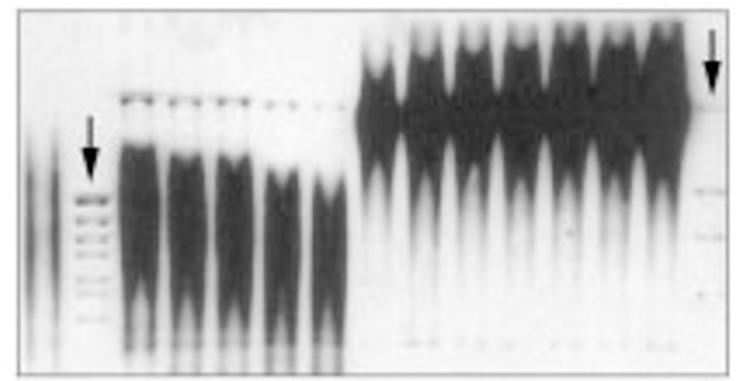

Figure 5. The changes of telomere length in various cell lines with serial subculture. (A) The telomere length of normal RPE cells was gradually shortened from $8.4 \mathrm{~kb}$ to $7.2 \mathrm{~kb}$ about $80 \mathrm{bp}$ loss per doubling as cells divided. The initial telomere length of the ST1 clone was longer than that of normal cells and it was shortened progressively. The ST1 clone expressed telomerase temporarily. (B) The telomere length of VR3 clone was shortened progressively from $7.8 \mathrm{~kb}$ to $5.8 \mathrm{~kb}$, which is shorter than that of normal RPE cells. The VR3 clone was selected after transfecting normal RPE cells with the T antigen. The initial telomere length of the ST2 clone $(14 \mathrm{~kb})$ was longer than that of normal cells like the ST1 clone, but the change of telomere length with passage was different. The elongated telomere length was maintained in the ST2 clone that expressed telomerase continuously. The numbers below N, ST1, VR3, and ST2 indicate population doublings. C, 293 control cells (11.3 Kb); LW, low molecular weight marker (8.6, 7.2, 6.4, and $5.7 \mathrm{~kb}$ from the top, left arrow); N, normal RPE cells; HW, high molecular weight marker (23.1, 9.4, 6.6, and $4.4 \mathrm{~kb}$ from the top, right arrow).

67 and stabilized at that length (Figure $5 \mathrm{~A}, \mathrm{~B}$ ).

\section{The origin of telomerase activity}

The 526 bp amplified product for ectopic hTERT mRNA was noted only in ST1 and ST2 clones with a primer set of RA58 and RA55. In contrast, the 508 bp product for endogenous hTERT mRNA was detected only in the KATO III stomach cancer cells with a primer set of RA58 and hTERT 3UTR. There were no detectable bands for endogenous and exogenous hTERT genes in normal RPE cells and VR3 cells. These results suggested that the ST1 and ST2 cells were successfully transfected with hTERT and express exogenous telomerase activity. 


\section{Discussion}

In this study, we have demonstrated that hTERT expression is required for transformed cells in pre-M2 stage to overcome M2 crisis and acquire an infinite lifespan. We have also demonstrated that the regulation of telomere length is related to the telomerase activity, and the telomere attrition may be an important factor responsible for the onset of cell proliferation crisis (M2) independently.

Previous studies have indicated that ectopic hTERT expression enables fibroblasts to circumvent senescence (Bodnar et al, 1998; Vaziri et al, 1998). In contrast, other reports claimed that hTERT expression alone is not sufficient to immortalize various human somatic epithelial cells but rather required to overcome M2 (O'Hare et al, 2001). The circumvention of M2 leads various epithelial cells in pre-M2 stage to the completely immortalized state as observed in SV40 T antigen transformed human embryonic kidney (HEK) cells, SV40 T antigen-Ras ${ }^{\text {Val112 }}$ transformed human fetal pancreatic epithelial cells (TRM-6), and adult pancreatic islet cell (Blox5) (Counter et al., 1998; Zhu et al., 1999; Halvorsen et al., 1999). Human skin keratinocytes and mammary epithelial cells were unable to be immortalized by hTERT expression alone either (Kiyono et al., 1998). Kiyno et al. also insisted that, in addition to telomerase activity, inactivation of the $\mathrm{Rb} / \mathrm{p} 16$ pathway by E7 protein of human papilloma virus 16 is also needed to immortalize these epithelial cells efficiently.

In our study, normal RPE cells was not be immortalized by hTERT transfection alone either, even though a number of clones were selected after the pGRN 145 vector was transfected (data not shown). Only SV40 T antigen-transformed pre-M2 cells could be immortalized after hTERT was transfected and expressed. Therefore, we assume that human somatic epithelial cells cannot be immortalized by telomerase activation alone, and the events to overcome M1 and M2 stages are independently processed to immortalize these cells. By our results and other reports, it may be concluded that the escape phenomenon from M2 by telomerase expression can be generalized to various epithelial cell types. O'Hare's et al (2001) also reported that ectopic expression of both telomerase and SV40 T antigen were required for immortalization of human mammary fibroblast and endothelial cells irrespective of the order in which they were introduced.

The effect of hTERT expression on the regulation of telomere length was also revealed in our study. Both ST1 and ST2 clones had significantly elongated telomere at the point of clonal expansion period after hTERT was transfected. However, the telomere length started to shorten as expressed telomerase faded out in the ST1 clone with a number of serial subculture. In contrast, the continuously telomerase-expressing ST2 clone maintained the telomere length during the entire observation period. These findings are consistent with those of O'Hare's report (2001).

The telomere attrition is known to be an important factor responsible for cell proliferation crisis (Campisi, 1997). Our results also suggest that the proliferative potential is linked to the telomere length because the telomere length of normal RPE cells, VR3 and ST1 cells was shortened markedly before they underwent growth arrest. Several hypotheses have been proposed to explain how telomere shortening induces change in the regulation of cell proliferation. The first hypothesis suggests that a critically shortened telomere triggers a DNA damage checkpoint that cells cannot recover (Goldstein, 1990; Harley et al., 1995). However, in this hypothesis several problems needed to be elucidated. That is, the p53 level that increase in the cells with the DNA damage response, is not elevated in senescent cells (Afshari et al., 1993; Oshima et al., 1995). In addition, if replicative senescence is a damage response, immortalization must overcome the damageinduced arrest and allow repair. However, cells reversibly immortalized by a conditional SV40 T antigen return to a growth-arrested state resembling senescence when the $T$ antigen is inactivated at a non-permissive temperature. In our study, the same finding was also observed. When tsT-transformed cells (VR3, ST1, and ST2 clones) were cultured at a non-permissive temperature, their proliferation ceased and their morphology altered to have more flat shape and enlarged cytoplasm. These are similar to the senescent phenotype (data not shown).

The second hypothesis is that telomeres may be bound or sequestered with various transcription factors that can regulate a variety of genes. As telomeres are shortened, these factors would be available to bind intragenomic target sites, where they could act to regulate genes important for cell cycle progression and maintenance of differentiated function (Marcand et al., 1995). Although this hypothesis can explain the complexity of the senescent phenotype change, currently no molecular data are available to support it. According to the third, the heterochromatic structure surrounding the telomere may contain the genes that regulate cell proliferation in repressed state. As telomeres are shortened, this repression is relieved and these genes may encode proteins that can arrest growth and/or alter differentiation (Wright et al., 1992). However, there is no enough evidence for such effects either.

The additional finding of our study is that both M1 and M2 events are retained even after the cells circumvent these stages. Namely, the M1 mechanism that was suppressed by $T$ antigen in both extended growth phase (VR3 clone) and immortal cells (ST1 and ST2 clones) reappeared after $\mathrm{T}$ antigen was inactivated at a non- 
permissive temperature. Moreover, the M2 mechanism that was overcome by ectopic telomerase expression was also resurrected after telomerase was spontaneously extinguished in the ST2 clone.

In conclusion, telomerase activation is required for human somatic epithelial cells to escape from M2 crisis and acquire an infinite lifespan, and telomere attrition may be a key factor responsible for the onset of cell growth arrest. Moreover, the M1 and M2 mechanisms are retained even after cells are immortalized.

\section{Acknowledgements}

We express our deep gratitude to Geron Corporation, $\mathrm{CA}$, USA for kindly providing human telomerase reverse transcriptase expressing vector, pGRN145 and Dr. J. Roy-Chowdhury of the Liver Research Center, Albert Einstein College of Medicine, NY, USA for kindly providing the $\varphi-2$ derived producer cell line for an amphotropic recombinant retrovirus containing the genes encoding tsT (early region mutant tsA58) and neomycin phosphotransferase. This work was partly supported by the grant from the 1999 Program of the Kyung Hee University.

\section{References}

Afshari CA, Voita PJ, Annab LA, Futreal PA, Willard TB, Barrett JC. Investigation of the role of $\mathrm{G} 1 / \mathrm{S}$ cell cycle mediators in cellular senescence. Exp Cell Res 1993;209:231-37

Bodnar AG, Ouellette M, Frolkis M, Holt SE, Chiu CP, Morin GB, Harley CB, Shay JW, Lichtsteiner S, Wright WE. Extension of life-span by introduction of telomerase into normal human cells. Science 1998;279:349-52

Campisi J. The Biology of replicative senescence. Eur J Cancer 1997;33:703-9

Counter CM, Hahn WC, Wei W, Caddle SD, Beijersbergen RL, Lansdorp PM, Sedivy JM, Weinberg RA. Dissociation among in vitro telomerase activity, telomere maintenance and cellular immortalization. Proc Natl Acad Sci U S A 1998;95:14723-28

Dell'Orco RT, Mertens JG, Kruse PF Jr. Doubling potential calendar time and senescence of human diploid cells in culture. Exp Cell Res 1973;77;356-60

Goldstein S. Replicative senescence: the human fibroblast comes of age. Science 1990;249:1129-33

Halvorsen T, Leibowitz G, Levine F. Telomerase activity is sufficient to allow transformed cells to escape from crisis. Mol Cell Biol 1999;19:1864-70

Harley CB, Futcher AB, Greider CW. Telomeres shorten during ageing of human fibroblasts. Nature 1990:345:458-60

Harley CB. Telomere loss: mitotic clock or genetic time bomb? Mutat Res 1991;256:271-82
Harley CB, Kim NW, Prowse KR, Weinrich SL, Hirsch KS, West MD, Bacchetti S, Hirte HW, Counter CM, Greider CW, Wright WE, Shay JW. Telomerase cell immortality and cancer. Cold Spring Harbor Symp Quant Biol 1994;59:307-15

Hastie ND, Dempster M, Dunlop MG, Thompson AM, Green DK, Allshire RC. Telomere reduction in human colorectal carcinoma and with ageing. Nature 1990;346:866-68

Hayflick L, Moorhead PS. The serial cultivation of human diploid strains. Exp Cell Res 1961;25:585-621

Kim BH, Sung SR, Choi EH, Kim YI, Kim KJ, Dong SH, Kim HJ, Chang YW, Lee JI, Chang R. Dedifferentiation of conditionally immortalized hepatocytes with long-term in vitro passage. Exp Mol Med 2000;32:29-37

Kim NW, Piatyszek MA, Prowse KR, Harley CB, West MD, Ho PLC, Coviello GM, Wright WE, Weinrich SL, Shay JW. Specific association of human telomerase activity with immortal cells and cancer. Science 1994;266:2011-15

Kiyono T, Foster SA, Koop JI, McDougall JK, Galloway DA, Klingelhutz Al. Both $\mathrm{Rb} / \mathrm{p} 16^{\text {ink4 }}$ inactivation and telomerase activity are required to immortalize human epithelial cells. Nature 1998;396:84-88

Levine AJ. Tumor suppressor genes. BioEssays 1990; 12:60-66

Marcand S, Buck SW, Moretti P, Gilson E, Shore D. Silencing of genes at non telomeric site in yeast is controlled by sequestration of silencing factors at telomeres by Rap 1 protein. Genes Dev 1995;10:1297-309

O'Hare MJ, Bond J, Clarke C, Takeuchi Y, Atherton AJ, Berry C, Moody J, Silver ARJ, Davies DD, Alsop AE, Neville AM, Jat PS. Conditional immortalization of freshly isolated human mammary fibroblasts and endothelial cells. Proc Natl Acad Sci U S A 2001;98:646-51

Oshima J, Campisi J, Tannock CA, Martin GM. Regulation of $c$-fos in senescing Werner syndrome fibroblast differ from that observed in senescing fibroblast of normal donors. J Cell Physiol 1995;162:277-83

Vaziri H'Benchimol S. Reconstitution of telomerase activity in normal human cells leads to elongation of telomeres and extended replicative life span. Current Biol 1998;8:279-82

Weinrich SL, Pruzan R, Ma L, Ouellette M, Tesmer VM, Holt SE, Bodnar AG, Lichtsteiner S, Kim NW, Trager JB, Taylor RD, Carlos R, Andrews WH, Wright WE, Shay JW, Harley CB. Morin GB. Reconstitution of human telomerase with the template RNA component hTR and the catalytic protein subunit hTRT. Nat Genet 1997;17:498-502

Wright WE, Periera-Smith OM, Shay JW. Reversible cellular senescence: implications for immortalization of normal human diploid fibroblasts. Mol Cell Biol 1989;9:3088-92

Wright WE, Shay JW. Telomere positional effects and the regulation of cellular senescence. Trend Genet 1992;8:193-97

Zhu J, Wang H, Bishop JM, Blackburn EH. Telomerase extends the lifespan of virus-transformed human cells without net telomere lengthening. Proc Natl Acad Sci U S A 1999;6:3723-28 